\title{
Fasciola bepatica infection and association with gastrointestinal parasites in Creole goats from western Argentina
}

Fasciola hepatica infecção e associação com parasitas gastrintestinais em caprinos crioulos do oeste da Argentina Pablo Cuervo $^{1}$; Laura Sidoti ${ }^{1}$; Cecilia Fantozzi ${ }^{1}$; Gisela Neira ${ }^{1}$; Leticia Gerbeno ${ }^{1}$; Roberto Mera y Sierra ${ }^{1 *}$

${ }^{1}$ Regional Parasitology Research Center - CIPAR, Faculty of Veterinary Sciences, University Juan A. Maza, Mendoza, Argentina

Received May 3, 2012

Accepted July 2, 2012

\begin{abstract}
Goats, called "the cow of the poor", are the livestock species with the most significant population growth worldwide in recent years. Gastrointestinal parasitism constitutes one of the main constraints to its outdoor and extensive breeding in temperate and tropical countries. Despite a Creole goat population of nearly 4 million heads, local reports on parasitological prevalence are scarce, and while Fasciola hepatica infection is spread all over Argentina, the goat is usually neglected as a reservoir and economic losses are not considered. To evaluate gastrointestinal parasitism prevalence and associations between parasite genera and species, with emphasis on fascioliasis, Creole goats from the plateau and Andean regions from western Argentina were investigated by coprological techniques, and associations were statistically assessed. Eighty-five percent (85\%) of the animals harbored one or more parasite types, while $46 \%$ showed mixed infections. Significant positive associations between F. hepatica + Strongyle eggs, Eimeria sp. + Nematodirus sp. and Nematodirus sp. + Trichuris ovis were detected. Further studies are required to define the causality of these associations and their relevance in epidemiology. F. hepatica is rarely considered as goat parasite in the country, but a $33 \%$ prevalence poses an interrogation on the role goats play on the transmission and dissemination of this zoonotic trematode.
\end{abstract}

Keywords: Caprine, fascioliasis, Wertern Argentina, Eimeria sp., Nematodirus, Trichuris ovis.

\section{Resumo}

As cabras, nomeadas como "a vaca dos pobres", são as espécies de gado com o crescimento populacional mais significativo nos últimos anos em todo o mundo. O parasitismo gastrintestinal constitui uma das principais limitaçôes à sua criaçáo extensiva em clima temperado e tropical. Na Argentina, apesar de uma população de caprinos crioulos de cerca de quatro milhôes de cabeças, são escassos os relatórios locais de prevalências parasitológicas. Embora a infecção por Fasciola hepatica esteja espalhada em todo o país, as cabras são geralmente negligenciadas como um reservatório, e as perdas econômicas não são consideradas. Para avaliar a prevalência do parasitismo gastrintestinal e associaçóes entre os gêneros e espécies de parasitos, com ênfase na fasciolose, caprinos crioulos da regiáo andina e do planalto do oeste de Argentina foram avaliados por meio de técnicas coprológicas. Oitenta e cinco por cento dos animais hospedaram um ou mais tipos de parasitos, enquanto $46 \%$ hospedaram infecçóes mistas. Foram encontradas associaçóes significativas entre F. hepatica + ovos de estrongilídeos, Eimeria sp. + Nematodirus sp. e Nematodirus sp. + Trichuris ovis. Mais estudos são necessários para definir a causalidade dessas associaçôes e sua relevância na epidemiologia. Raramente $F$. hepatica é considerada como um parasito de cabra no país, mas uma prevalência de 33\% suscita uma interrogaçáo sobre o papel dos caprinos na transmissão e disseminação desse trematódeo zoonótico.

Palavras-chave: Caprinos, fasciolose, Oeste da Argentina, Eimeria sp., Nematodirus, Trichuris ovis.

\section{Introduction}

Goat exploitation is an example of a sustainable production that is fully integrated within the local rural development, being the domestic livestock species with the most significant population growth worldwide in recent years, mainly in developing countries

*Corresponding author: Roberto Mera y Sierra

Facultad de Ciencias Veterinarias y Ambientales, Universidad Juan A. Maza,

Av. Acceso Este, Lat. Sur, 2245, Mendoza, Argentina

e-mail: cipar.umaza@gmail.com
(MORAND-FEHR et al., 2004; BOYAZOGLU et al., 2005). Its current success appears to be related with two characteristics: i) goats are efficient converters of low-quality forages into quality products, and ii) constitute a source of high quality protein; both of them high valuable properties in farming systems with limited resources (LEBBIE, 2004; BOYAZOGLU et al., 2005), such as those present in most developing countries (LEBBIE, 2004). These characteristics may explain the frequent labeling of goats as "the 
cow of the poor", highlighting its importance in small farming systems (BOYAZOGLU et al., 2005; HOSTE et al., 2010).

Gastrointestinal parasitism constitutes one of the main constraints to the outdoor and extensive breeding of goats in temperate and tropical countries (HOSTE et al., 2005, 2008; COELHO et al., 2012). For years, it has been considered that data obtained on parasite infections in sheep could be directly transferred to goats (HOSTE et al., 2010), and thus disregarding specific studies on goat parasitism and its consequences. However, in recent years, accumulated information have underlined the fact that gastrointestinal parasitism in goats differed in many aspects to that in sheep (HOSTE et al., 2008), and thus studies in the area are encouraged (SAHLU; GOETSCH, 2005).

The goat population in Argentina reaches about 4 million heads, mainly distributed in the harsh and dry environments of the central and western regions. The dominant flocks are of Creole goats, derived from introductions during the Spanish colonial times, and mainly owned by small holders, usually belonging to the most marginalized sector of the population. Animals are raised extensively, grazing rangelands during the day and housed during the nights in rustic corrals near the households (DE GEA et al., 2005).

Fascioliasis, caused in the Americas by the trematode Fasciola hepatica (MAS-COMA et al., 2009), produces a serious economic impact (reduction in milk and meat production, liver condemnation, reproductive failure and mortality) in the livestock industry (KAPLAN, 2001; SCHWEIZER et al., 2005). Despite the mentioned economic impact and an emergent, potentially important, goat production in South America (DUBEUF et al., 2004), goat fascioliasis is mainly neglected in the sub-continent. In Argentina, according to official slaughterhouse records, animal fascioliasis covers the whole country (MERA Y SIERRA et al., 2011), but this information only comprises cattle and sheep, and rarely involves goats. Despite goat fascioliasis in the country not being even considered (ROSSANIGO, 2007), there are few, usually opportunistic, reports of infection, but demonstrating high local prevalence rates (AGUIRRE et al., 2005; RUBEL et al., 2005; ISSIA et al., 2009).

The aim of this study was to determine i) the prevalence rates of gastrointestinal parasites, ii) single and multiple infections, and iii) statistical associations, with special emphasis on liver fluke F. hepatica, in Creole goats from the plateau and Andean regions of western Argentina

\section{Materials and Methods}

\section{Feces collection and laboratory methods}

Six hundred sixty-three (663) Creole goats born in the plateau and Andean regions of Mendoza (623), San Juan (16) and La Rioja (24) provinces (western Argentina) were surveyed between June 2006 and December 2011. Samples were sent by private practitioners, who requested coproparasitological analysis. Individuals were selected by convenience and fecal samples were directly collected from the rectum. The collected samples were labeled, refrigerated and transported to the laboratory for examination. Coproparasitological exams were systematically performed by means of three methods: Sheater's flotation technique (SHEATHER, 1923), Ritchie's formol-ether concentration technique (RITCHIE, 1948) and Lumbreras technique (LUMBRERAS et al., 1962). Fecal culture and larvae identification were performed when sufficient material from positive samples was available (NIEC, 1968).

\section{Statistical analysis}

Statistix ${ }^{\oplus}$ for Windows 7.0 and SPSS $^{\oplus}$ for Windows 17.0 software programs were used for statistical analysis, comparison of categorical variables and chi-square test. Chi-square test was applied for comparison between observed and expected prevalence.

Associations between $F$. hepatica and other parasite types were investigated by $2 \times 2$ contingency tables, from which the chi-square was calculated. First, each parasite type occurrence was compared to each other; and then, $F$. hepatica occurrence was compared with pairs of parasite types (in each threesome, all combinations possible were tested). Due to small $N$ and loss of statistical power, no further comparisons were investigated. Values of $P<0.05$ were taken as significant. Odds Ratio (OR), OR confidence interval (95\%) and Relative Risk (RR) were calculated in cases where significant positive association was detected. Considering that, unlike $\mathrm{OR}$, the calculation of $\mathrm{RR}$ is influenced by the position of the variable in the $2 \times 2$ contingency table, both combinations were tested.

\section{Results}

Out of the total 663 goats examined, 84.8\% (562) were found to host one or more parasite types (as described in Table 1). Among the infected animals, $46 \%$ hosted mixed infections. $64.7 \%$ of the animals were infected with a protozoan species and $63.49 \%$ with at least one helminth species. Two hundred and seventeen (32.9\%) of the examined animals (659) were positive for F. hepatica, 344 (51.88\%) were positive for nematodes, while 422 (64.72\%) were positive for Eimeria sp. oocysts (Table 1).

Following the few reports available (AGUIRRE et al., 2005; RUBEL et al., 2005; ISSIA et al., 2009), expected prevalence could only be determined for $F$. hepatica infection (94.7\%), being the observed prevalence $(32.9 \%)$ significantly lower than expected $(P<0.05)$.

The prevalence rates of single and multiple parasite type infections are shown in Table 2. Considering presence of parasite types, single presence (38.61\%) was the most common, with Eimeria sp. as the predominant type (21.27\%), followed by double presence $(31.82 \%)$. The most frequent combinations were Eimeria sp. + Nematodirus sp. (15.38\%) and Fasciola hepatica + Eimeria sp. (11.01\%).

F. hepatica occurred mainly as a co-infection with another parasite, while only $22.12 \%$ (48) of the total cases of fascioliasis (217) occurred as monoparasitism (Table 2). It was most frequently combined with Eimeria sp. (11.01\%), followed by the duet F. hepatica + Nematodirus sp. (2.11\%), and lastly combined with Strongyle eggs $(0.90 \%)$. 
Table 1. Observed prevalence rates of parasite infection among 663 Creole goats in the plateau and Andean regions, Argentina (overall and per province surveyed).

\begin{tabular}{|c|c|c|c|c|c|}
\hline Parasites & $N$ & \% Infect. (CI 95) & Mza (\%) & S. Juan (\%) & La Rioja (\%) \\
\hline All & 663 & $84.8(82.2-87.3)$ & 623 & 16 & 24 \\
\hline Strongyle eggs & 652 & $9(6.9-11)$ & $42(6.74)$ & 0 & $17(70.83)$ \\
\hline Nematodirus sp. & 663 & $40.6(37.1-44.1)$ & $265(42.54)$ & $2(12.5)$ & $2(8.33)$ \\
\hline T. ovis & 663 & $2.3(1.2-3.4)$ & $15(5.7)$ & 0 & 0 \\
\hline F. hepatica & 659 & $32.9(29.6-36.2)$ & $208(33.39)$ & 0 & $9(37.5)$ \\
\hline Eimeria sp. & 652 & $64.7(61.3-68.1)$ & $414(66.45)$ & $1(6.25)$ & $7(29.17)$ \\
\hline
\end{tabular}

\% Infect.: \% of infection; Mza: Mendoza province; S. Juan: San Juan province.

Table 2. Combination of infecting parasites among 663 Creole goats in the plateau and Andean regions, Argentina (combinations with less than $0.5 \%$ are not shown).

\begin{tabular}{lc}
\hline \multicolumn{1}{c}{ Parasites of combination } & No (\%) \\
\hline Any single type & $256(38.61)$ \\
Strongyle eggs & $8(1.21)$ \\
Nematodirus sp. & $59(8.90)$ \\
F. hepatica & $48(7.24)$ \\
Eimeria sp. & $141(21.27)$ \\
Double combination & $211(31.82)$ \\
F. hepatica + Eimeria sp. & $73(11.01)$ \\
F. hepatica + Strongyle eggs & $6(0.90)$ \\
F. hepatica + Nematodirus sp. & $14(2.11)$ \\
Eimeria sp. + Strongyle eggs & $11(1.66)$ \\
Eimeria sp. + Nematodirus sp. & $102(15.38)$ \\
Triple combination & $77(11.61)$ \\
F. hepatica + Eimeria sp. + Nematodirus sp. & $53(7.99)$ \\
Eimeria sp. + Strongyle eggs + Nematodirus sp. & $10(1.51)$ \\
Eimeria sp. + Nematodirus sp. + T. ovis & $8(1.21)$ \\
Quadruple combination & $17(2.56)$ \\
F. hepatica + Eimeria sp. + Strongyle eggs & $16(2.41)$ \\
+ Nematodirus sp. &
\end{tabular}

Due to insufficient material (feces) and low eggs per gram (mean $158.4 \mathrm{epg}$ ), results from fecal culture for larvae identification were obtained only with the positive samples from La Rioja province. Trichostrongylus sp. were identified in every sample cultured (15), while 9 samples were positive to Haemonchus sp., 2 to Oesophagostomum sp. and 1 to Ostertagia sp. The overall prevalence rates found was: Trichostrongylus sp. 95.81\%, Haemonchus sp. 3.11\%, Oesophagostomum sp. 0.95\% and Ostertagia sp. $0.14 \%$.

Chi-square association tests revealed significant positive associations between F. hepatica and Strongyle eggs, Eimeria sp. and Nematodirus sp., and Nematodirus sp. and T. ovis (Table 3).

When $F$. hepatica occurrence was compared with pairs of parasite types and possible combinations, significant positive associations were found in the following threesomes: F. hepatica + Eimeria sp. + Nematodirus sp., $F$. hepatica + Eimeria sp. + Strongyle eggs, and F. hepatica + Strongyle eggs + Nematodirus sp. (See Table 3 for details).

\section{Discussion}

To the authors' knowledge, this study is the first to report precise goat parasites prevalence rates in western Argentina. As usual, and in accordance with previous world tendencies, goat parasitism in the country has been frequently disregarded, and such valuable information not informed due to general disinterest. Most of the available local studies only informed about seasonality of gastrointestinal parasites fecal counts and treatment results, but gave no information about local prevalence that allowed further epidemiological comparison.

This study reveals a high overall prevalence of gastrointestinal parasites, reaching almost 85\% - maximum for Eimeria sp. (64.7\%) and minimum for Trichuris ovis (2.3\%). Meanwhile, the high prevalence $(32.9 \%)$ of $F$. hepatica is remarkable.

Due to the mentioned scarcity of local data regarding prevalence of goat gastrointestinal parasitism, observed and expected values could only be compared in the case of infection by $F$. hepatica, which was significantly lower than expected $(P<0.05)$ (Table 1$)$. In the few national reports where $F$. hepatica infection in goats was described (AGUIRRE et al., 2005; RUBEL et al., 2005; ISSIA et al., 2009), studies were developed in response to outbreaks, sample numbers were small, and individuals sampled belonged to the same herd, thus explaining the very high local prevalence and the consequent difference between observed and expected values.

The status of polyparasitism using coproscopy as the method indicated that almost half $(46.1 \%)$ of these animals harbored 2-5 different parasite eggs. Despite the numerous parasite combinations observed (Table 2 ), significant positive associations $(P<0.05)$ were detected only between $F$. hepatica + Strongyle eggs, Eimeria sp. + Nematodirus sp. and Nematodirus sp. + T. ovis (Table 3).

In the first case, F. hepatica + Strongyle eggs, the association could be non-causal (confounding factor), possibly due to favorable environmental characteristics for the development of larvae and infection in the same places where infection with $F$. hepatica occurs (e.g. swamps and waterlogged areas). On the other hand, the OR and RR analysis suggests that infection by F. hepatica may act as a contributing factor for Strongyle infection, enhancing almost twice (1.96 and 1.83 respectively) the odds, probably due to the host immunosuppression attributed to the trematode (CERVI et al., 1996; SIDOTI, 2011) or just due to a more vulnerable host (a host's weakened state) (BEGON et al, 2006). Considering that most of the larvae identified belonged to the family Trichostrongylidae, association could also be attributed to the arrested larvae released by the suggested immunosuppression (ANDERSON, 2000). 
Table 3. Associations between gastrointestinal parasite among 663 Creole goats in the plateau and Andean regions, Argentina.

\begin{tabular}{cccc}
\hline Parasite sp. & $\chi^{2}$ & P-value & OR (CI 95\%) \\
\hline F. hepatica* Strongyle eggs & 6.11 & 0.0134 & $1.96(1.14-3.36)$ \\
Eimeria sp. $^{*}$ Nematodirus sp. & 7.91 & 0.0049 & $1.61(1.15-2.25)$ \\
Nematodirus sp. $^{*}$ T. ovis & 9.89 & 0.0017 & $6.09(1.70-21.78)$ \\
Eimeria sp. $^{*}$ F. hepatica + Nematodirus sp. & 12.54 & 0.0004 & $2.70(1.53-4.78)$ \\
Nematodirus sp. ${ }^{*}$ F. hepatica + Eimeria sp. & 4.68 & 0.0306 & $1.50(1.04-2.17)$ \\
F. hepatica* Eimeria sp. + Strongyle eggs & 4.38 & 0.0363 & $1.94(1.03-3.63)$ \\
Strongyle eggs* F. hepatica + Eimeria sp. & 4.79 & 0.0287 & $1.88(1.06-3.34)$ \\
F. hepatica* Strongyle eggs + Nematodirus sp. & 13.2 & 0.0003 & $3.76(1.76-8.05)$ \\
Strongyle eggs* F. hepatica + Nematodirus sp. & 19.9 & 0.0000 & $3.67(2.01-6.69)$ \\
Nematodirus sp. ${ }^{*}$ F. hepatica + Strongyle eggs & 9.03 & 0.0027 & $3.25(1.45-7.30)$ \\
\hline
\end{tabular}

* Significant associations.

The significant association observed between Eimeria sp. + Nematodirus sp. and Nematodirus sp. + T. ovis could be a consequence of infective stages (oocysts and eggs) resistant to extreme environmental conditions or related to housing conditions, with animals returning to corrals every day and manure being accumulated during months.

When complex associations were evaluated, significant positive associations were detected in three sets of combinations: F. hepatica + Eimeria sp. + Nematodirus sp., F. hepatica + Eimeria sp. + Strongyle eggs, and $F$. hepatica + Strongyle eggs + Nematodirus sp. (Table 3). In the first two threesomes, the association observed is attributed to the significant associations detected when analyzing by pairs (Eimeria sp. + Nematodirus sp. and $F$. hepatica + Strongyle eggs), even more when the third parasite type (F. hepatica and Eimeria sp., respectively) is tested against the associated pair and no significant association is detected. It is worth noting the last threesome, where, following the previous criteria, the presence of eggs of Nematodirus sp. is significantly associated with the combination $F$. hepatica + Strongyle eggs $\left(\chi^{2}=9.03, P=0.0027\right)$.

Further studies are required to define whether these associations are causal or not, and their relevance in the epidemiology of the parasite types implicated. Future studies should also analyze the economic losses generated by goat gastrointestinal multiparasitism, especially considering its impact on local extensive small farming systems.

As highlighted before, $F$. hepatica is rarely considered as a parasite of goats in the country. Consequently, not only the recognized economic losses are not analyzed, but also this ruminant is neglected as an important reservoir of this zoonosis. Furthermore, the stunning $33 \%$ prevalence detected poses an interrogation and alerts about the role goats play on the transmission and dissemination of this zoonotic trematode.

\section{Acknowledgements}

This research was funded by "Área de Ciencia y Técnica, Universidad Juan A. Maza”, Mendoza, Argentina.

\section{References}

Aguirre DH, Cafrune MM, Salatin AO, Abeyá AA. Fasciolosis clínica en cabras de Metán (Salta, Argentina). Rev FAVE - Cienc Vet 2005; 4(1-2): 17-21.

Anderson RC. Nematode parasites of vertebrates: Their development and transmission. 2nd ed. Wallingford: CAB International; 2000. http:// dx.doi.org/10.1079/9780851994215.0000

Begon M, Townsend CR, Harper JL. Ecology: from individuals to ecosystems. 4th ed. Oxford: Blackwell Publishing; 2006.

Boyazoglu J, Hatziminaoglou I, Morand-Fehr P. The role of the goat in society: past, present and perspectives for the future. Small Ruminant Res 2005; 60(1-2): 13-23. http://dx.doi.org/10.1016/j. smallrumres.2005.06.003

Cervi L, Rubinstein H, Masih DT. Involvement of excretion-secretion products from Fasciola hepatica inducing suppression of the cellular immune responses. Vet Parasitol 1996; 61(1-2): 97-111. http://dx.doi. org/10.1016/0304-4017(95)00816-0

Coelho WM, Amarante AF, Bresciani KD. Ocurrence of gastrointestinal parasites in goat kids. Rev Bras Parasitol Vet 2012; 21(1): 65-67. PMid:22534948. http://dx.doi.org/10.1590/ S1984-29612012000100013

De Gea G, Petryna AM, Mellano A, Bonvillani A, Turiello P. El ganado caprino en la Argentina: Antecedentes para su estudio. Córdoba: Universidad Nacional de Río Cuarto; 2005.

Dubeuf JP, Morand-Fehr P, Rubino R. Situation, changes, and future of goat industry around the world. Small Ruminant Res 2004; 51(2): 165-173. http://dx.doi.org/10.1016/j.smallrumres.2003.08.007

Hoste H, Torres-Acosta JF, Paolini V, Aguilar-Caballero A, Etter E, Lefrileux Y, et al. Interactions between nutrition and gastrointestinal infections with parasitic nematodes in goats. Small Ruminant Res 2005; 60(1-2): 141-151. http://dx.doi.org/10.1016/j. smallrumres.2005.06.008

Hoste H, Torres-Acosta JF, Aguilar-Caballero AJ. Nutrition-parasite interactions in goats: is immunoregulation involved in the control of gastrointestinal nematodes? Parasite Immunol 2008; 30(2): 79-88. PMid:18186768. 
Hoste H, Sotiraki S, Yan Landau S, Jackson F, Beveridge I. Goat-nematode interactions: think differently. Trends Parasitol 2010; 26(8): 376-381. PMid:20488752. http://dx.doi.org/10.1016/j.pt.2010.04.007

Issia L, Pietrokovsky S, Sousa-Figueiredo J, Russell Stothard J, Wisnivesky-Colli C. Fasciola hepatica infection in livestock flocks, guanacos and coypus in two wildlife reserves in Argentina. Vet Parasitol 2009; 165(3-4): 341-344. PMid:19700244. http://dx.doi. org/10.1016/j.vetpar.2009.07.011

Kaplan RM. Fasciola hepatica: a review of the economic impact in cattle and considerations for control. Vet Ther 2001; 2(1): 40-50. PMid:19753697.

Lebbie SHB. Goats under household conditions. Small Ruminant Res 2004; 51(2): 131-136. http://dx.doi.org/10.1016/j. smallrumres.2003.08.015

Lumbreras H, Cantella R, Burga R. Acerca de un procedimiento de sedimentación rápida para investigar huevos de Fasciola hepatica en las heces, su evaluación y uso en el campo. Rev Med Peru 1962; 31(332): 167-174.

Mas-Coma S, Valero MA, Bargues MD. Chapter 2. Fasciola, lymnaeids and human fascioliasis, with a global overview on disease transmission, epidemiology, evolutionary genetics, molecular epidemiology and control. Adv Parasitol 2009; 69: 41-146. http://dx.doi.org/10.1016/ S0065-308X(09)69002-3

Mera y Sierra R, Agramunt VH, Cuervo P, Mas-Coma S. Human fascioliasis in Argentina: retrospective overview, critical analysis and baseline for future research. Parasite Vectors 2011; 4: 104. PMid:21663691 PMCid:3141741. http://dx.doi.org/10.1186/1756-3305-4-104

Morand-Fehr P, Boutonnet JP, Devendra C, Dubeuf JP, Haenlein GFW, Holst P, et al. Strategy for goat farming in the 21 st century. Small
Ruminant Res 2004; 51(2): 175-183. http://dx.doi.org/10.1016/j. smallrumres.2003.08.013

Niec R. Cultivo e identificación de larvas infectantes de nemátodes gastrointestinales del bovino y ovino. Buenos Aires: INTA; 1968. Manual técnico n. 3.

Ritchie LS. An ether sedimentation technique for routine stool examination. Bull US Army Med Dep 1948; 8(4): 326.

Rossanigo CE. Parasitosis de las cabras. In: Suárez VH, Olaechea FV, Rossanigo CE, Romero JR. Enfermedades parasitarias de los ovinos y otros rumiantes menores en el cono sur de América. EEA Anguil, INTA; 2007. p. $247-270$.

Rubel D, Prepelitchi L, Kleiman F, Carnevale S, Wisnivesky-Colli C. Estudio del foco en un caso de fasciolosis humana en Neuquén. Medicina 2005; 65(3): 207-212.

Sahlu T, Goetsch AL. A foresight in goat research. Small Ruminant Res 2005; 60(1-2): 7-12. http://dx.doi.org/10.1016/j. smallrumres.2005.06.002

Schweizer G, Braun U, Deplazes P, Torgerson PS. Estimating the financial losses due to bovine fasciolosis in Switzerland. Vet Rec 2005; 157(7): 188193. PMid:16100368.

Sheather AL. The detection of intestinal protozoa and mange parasites by a flotation technique. J Comp Pathol 1923; 36: 266-275. http://dx.doi. org/10.1016/S0368-1742(23)80052-2

Sidoti LE. Diagnóstico de Fascioliasis bovina mediante coprología y serología, y relación con parámetros hematológicos y bioquímicos [Thesis]. Mendoza: Facultad de Ciencias Veterinarias y Ambientales, Universidad Juan A. Maza; 2011. 